\title{
Efficacy of prophylactic tranexamic acid administration in prevention of postpartum hemorrhage in placenta previa cesarean section: an interventional study
}

\author{
Monika Rathore*, Anjali Gupta, Nidhi Kumari
}

Department of Obstetrics and Gynecology, Pt. B.D. Sharma PGIMS, Rohtak, Haryana, India

Received: 25 October 2021

Accepted: 10 November 2021

\author{
*Correspondence: \\ Dr. Monika Rathore, \\ E-mail: monikarathore171@gmail.com
}

Copyright: (C) the author(s), publisher and licensee Medip Academy. This is an open-access article distributed under the terms of the Creative Commons Attribution Non-Commercial License, which permits unrestricted non-commercial use, distribution, and reproduction in any medium, provided the original work is properly cited.

\begin{abstract}
Background: Postpartum hemorrhage accounts for the major part of the mortality as well as morbidity like severe anemia, need for blood transfusion, hospital stay and infection. Aim and objectives of the study were to determine the efficacy and safety of prophylactic tranexamic acid and intravenous tranexamic acid in preventing postpartum hemorrhage in women undergoing caesarean section for placenta previa.

Methods: Seventy women with placenta previa over 1 year, randomized into 2 groups: group 1 ( $\mathrm{n}=35$ ): Women who received $10 \mathrm{IU}$ oxytocin intravenous infusion after placental delivery and group $2(\mathrm{n}=35)$ : Women who received 1 gm $(10 \mathrm{ml})$ tranexamic acid IV before skin incision plus $10 \mathrm{IU}$ oxytocin intravenous infusion after placental delivery.

Results: The mean age was similar in 2 groups i.e., 26.34 \pm 4.78 years in group 1 and 27.31 \pm 5.62 years in group 2. Most women in the present study presented with type IV placenta previa i.e., $34.3 \%$ in group 1 and $48.6 \%$ in group 2. Mean pre-operative hemoglobin was $9.57 \pm 1.54 \mathrm{~g} / \mathrm{dl}$ in group 1 and $9.59 \pm 1.35 \mathrm{~g} / \mathrm{dl}$ in group 2 . Intra-operative mean blood loss was $729.31 \pm 172.45 \mathrm{ml}$ in intravenous oxytocin group and $464.86 \pm 28.00 \mathrm{ml}$ in intravenous tranexamic acid group. A total of $74.3 \%$ women in group 1 and $20 \%$ women in group 2 developed postpartum hemorrhage. Mean post-operative hemoglobin was $8.04 \pm 1.34 \mathrm{~g} / \mathrm{dl}$ in group 1 and $8.85 \pm 1.26 \mathrm{~g} / \mathrm{dl}$ in group 2 . In group $1,5.7 \%$ neonates were born with very low birth weight and while none in group 2. 51.4\% neonates in group 1 and $45.7 \%$ in group 2 had low birth weight. Conclusions: It is concluded that tranexamic acid used prophylactically intravenously before skin incision in patients undergoing cesarean section for placenta previa significantly reduces intra-operative blood loss.
\end{abstract}

Keywords: Prophylactic tranexamic acid, Postpartum hemorrhage, Placenta previa, Cesarean section

\section{INTRODUCTION}

Every year over five lac women die worldwide due to causes related to pregnancy and delivery. Postpartum hemorrhage accounts for the major part of the mortality as well as morbidity like severe anemia, need for blood transfusion, hospital stay and infection. Obstetric hemorrhage is responsible for about $30 \%$ all pregnancy related deaths in both high- and low-income countries and is the leading direct etiology of maternal mortality worldwide. ${ }^{1}$ Most of the deaths occur soon after giving birth and almost all (99\%) occur in low- and middle- income countries. Fourteen million women suffer from postpartum hemorrhage each year, of whom 1-2\% die within 2-4 hours after the onset of bleeding, 2 to $11 \%$ of them show anemia later in their life. ${ }^{2}$

The rates of cesarean section have increased to as high as $25 \%$ to $30 \%$ in many areas of the world. ${ }^{3}$ Postpartum hemorrhage complicates approximately six percent of the cesarean sections. According to world health organization definition, postpartum hemorrhage occurs when the clinical amount of blood loss is about $500 \mathrm{ml}$ after vaginal delivery or $1000 \mathrm{ml}$ after caesarean section. ${ }^{4}$ Risk factors 
for postpartum hemorrhage include previous postpartum hemorrhage, primiparity, obesity, prolonged or augmented labour, multiple pregnancies, previous cesarean delivery, polyhydramnios, macrosomia and placenta previa. ${ }^{5,6}$

Postpartum hemorrhage is commonly encountered following placenta previa as one of the major causes. Traditionally, four variations of placenta previa were recognized-complete, partial, marginal and low-lying. ${ }^{7}$ Recent revised classification of placenta previa consists of two variations: true placenta previa, in which the internal cervical OS is covered by placental tissue and low-lying placenta, in which the placenta lies within $2 \mathrm{~cm}$ of the cervical OS but does not cover it. ${ }^{8}$

Over many years, several techniques have been described in the literature for controlling massive bleeding associated with placenta previa cesarean sections, including uterine packing with gauze, balloon tamponades, B-Lynch suture, insertion of parallel vertical compression sutures, a square suturing technique and embolization or ligation of the uterine and internal iliac arteries, but there is wide variation in success rate of these maneuvers. ${ }^{9-13}$

Tranexamic acid has been shown to be very useful in reducing blood loss and incidence of blood transfusion in various surgeries such as coronary artery bypass, scoliosis surgery, oral surgery, orthotopic liver transplantation etc. In gynecology, tranexamic acid reduces maternal blood loss in women with menorrhagia compared with control agents/placebo. In obstetrics, it reduces bleeding related mortality in women with postpartum hemorrhage, especially when administered fairly soon after delivery. ${ }^{14}$

In light of these observations and in view of limited evidence on use of tranexamic acid for prevention of bleeding during caesarean section in cases of placenta previa, present study was conducted to determine efficacy and safety of intravenous tranexamic acid in preventing postpartum hemorrhage in women undergoing caesarean section for placenta previa.

\section{METHODS}

This prospective interventional randomized controlled study was conducted on women with placenta previa who underwent caesarean section in department of obstetrics and gynecology at Pt. B. D. Sharma, PGIMS, Rohtak, Haryana. The study was conducted over a period of one year (October 2018 to September 2019).

Women with placenta previa undergoing cesarean section were included in the present study and women with cardiac, hepatic, renal, thromboembolic disease, placenta accreta and allergy to tranexamic acid were excluded.

\section{Method of recruitment}

Subjects were enrolled in the study after taking written informed consent and explaining in details about the study protocol. The diagnosis of placenta previa was made on the basis of ultrasonography. Participants were randomized into two groups based on computerized generated method: Group $1(\mathrm{n}=35)$ : included patients who received $10 \mathrm{IU}$ oxytocin intravenous infusion after placental delivery. Group $2(\mathrm{n}=35)$ : included patients who received 1 gram $(10 \mathrm{ml})$ tranexamic acid intravenous before skin incision plus 10 IU oxytocin intravenous infusion after placental delivery.

\section{Intervention}

$10 \mathrm{IU}$ oxytocin intravenous infusion in $500 \mathrm{ml}$ normal saline over 30 minutes was given in both the group. One gram $(10 \mathrm{ml})$ tranexamic acid was given by slow intravenous injection just before skin incision. The detailed history and thorough clinical examination of all subjects was done. All were subjected to investigations namely haemoglobin, blood group, HIV, HBsAg, VDRL, glucose challenge test, TSH, complete urine examination and ultrasonography. Patients' blood pressure and pulse were taken. Hemoglobin concentration was done preoperatively and 24 hours postoperatively and change in hemoglobin concentration was noted. The patients were followed up till discharge. Any maternal morbidity and mortality were also noted.

Primary outcome was measured in terms of blood loss: Quantity of blood loss in $\mathrm{ml}=$ [weight of gauze pads used after surgery-weight of gauze pads used before surgery] + volume of blood in suction bottle after placental delivery.

Secondary outcome was measured in terms of need for blood transfusion, need of uterotonics and need of additional surgical intervention like uterine artery ligation or uterine compression sutures.

\section{Statistical analysis}

At the end of the study, all data was compiled and the statistics were analyzed with SPSS version 21. Continuous variables were presented as mean $\pm \mathrm{SD}$ or median for the unevenly distributed data. Categorical variables were expressed as frequencies and percentages. Association between two or more variables was compared using chi square test. For all statistical tests, a $\mathrm{p}<0.05$ was considered statistically significant.

\section{RESULTS}

The present prospective interventional randomized controlled study was conducted on 70 women $(n=35$ in each group) with placenta previa undergoing caesarean section over a period of one year (October 2018 to September 2019). The mean age was $26.34 \pm 4.78$ years in group 1 and $27.31 \pm 5.62$ years in group 2 ( $>>0.05)$. Most women in the present study were nullipara that is $42.9 \%$ were in group 1 and $48.6 \%$ in group $2(\mathrm{p}>0.05)$. Mean body weight was $62.97 \pm 6.44 \mathrm{~kg}$ in group 1 and $63.2 \pm 6.12$ $\mathrm{kg}$ in group $2(\mathrm{p}>0.05)$. Mean systolic blood pressure in 
group 1 and 2 was $115.49 \pm 8.7$ and $112.74 \pm 8.79 \mathrm{mmHg}$ respectively ( $p>0.05 \mathrm{NS})$, mean diastolic blood pressure was $76.29 \pm 8.32$ and $75.37 \pm 8.21$ ( $>>0.05 \mathrm{NS}) \mathrm{mmHg}$ respectively and mean pulse rate was $94.57 \pm 8.7$ and $91.77 \pm 6.74$ per minute respectively ( $p>0.05 \mathrm{NS})$.

Bleeding per vaginum was present in $91.4 \%$ in group 1 and $77.1 \%$ in group 2. Labour pain was present in $0 \%$ and $11.4 \%$ in group 1 and 2 respectively $(p>0.05)$. Women who had no previous cesarean section in group 1 and 2 was $77.1 \%$ and $80 \%$ respectively ( $p>0.05$ ). In group $1,17.1 \%$ and in group 2, $25.7 \%$ women presented with malpresentation. Malpresentation included breech, oblique and transverse lie. In group $1,5.7 \%$ women and in group 2, 2.9\% women had absent fetal heart sound on ultrasonography indicating intrauterine death of fetus at the time of presentation. Most women presented with type IV placenta previa in both the groups followed by type III and type IIb. Women with type IV placenta previa were $34.3 \%$ in group 1 and $48.6 \%$ in group $2(p>0.05)$.

Pre-operative hemoglobin level in most women was in range of $9-10.9 \mathrm{~g} / \mathrm{dl}$ that includes $48.6 \%$ in group 1 and $71.4 \%$ in group 2 . In present study, $2.9 \%$ women in group 1 and $8.6 \%$ in group 2 were found to be severely anemic. Mean pre-operative hemoglobin level was $9.57 \pm 1.54 \mathrm{~g} / \mathrm{dl}$ in group 1 and $9.59 \pm 1.35 \mathrm{~g} / \mathrm{dl}$ in group 2 . No statistically significant difference was found between both groups in terms of mean pre-operative hemoglobin level ( $p>0.05$ ). Mean INR was $1 \pm 0.12$ in group 1 and $0.99 \pm 0.14$ in group 2 . The mean platelet count was found to be $2.07 \pm 0.71$ lac in group 1 and $2.01 \pm 0.39$ lac in group 2 ( $p>0.05 \mathrm{NS}$ ).

Majority of the women in the present study did not require pre-operative blood transfusion. Blood transfusion was given pre-operatively to $5.8 \%$ women in group 1 and $8.6 \%$ in group 2 in form of packed cell. Mean requirement of pre-operative blood transfusion was $0.086 \pm 0.368$ units in group 1 and $0.143 \pm 0.486$ units in group 2 . The difference was found to be statistically insignificant $(p>0.05)$.

A total of $60 \%$ of women in group 1 and $45.7 \%$ in group 2 delivered at $32-36+6$ weeks. Mean gestational age at delivery was $35.77 \pm 2.66$ weeks in group 1 and $36.69 \pm 2.35$ weeks in group 2. No statistically significant difference was observed between groups in terms of gestational age at delivery $(\mathrm{p}>0.05)$.

Table 1: Intra-operative mean blood loss, $(\mathrm{n}=35)$.

\begin{tabular}{|c|c|c|c|}
\hline $\begin{array}{l}\text { Blood loss } \\
(\mathrm{ml})\end{array}$ & $\begin{array}{l}\text { Group 1, } \\
\text { n (\%) }\end{array}$ & $\begin{array}{l}\text { Group 2, } \\
\text { n }(\%)\end{array}$ & $\begin{array}{l}\text { P value } \\
(95 \% \mathrm{CI})\end{array}$ \\
\hline $200-400$ & $0(0)$ & $19(54.3)$ & \multirow{6}{*}{$\begin{array}{l}<0.001 \\
{[95 \% \mathrm{CI}=} \\
165.51 \text { to } \\
363.41]\end{array}$} \\
\hline $400-600$ & $9(25.7)$ & $10(28.6)$ & \\
\hline $600-800$ & $15(42.9)$ & $4(11.4)$ & \\
\hline $800-1000$ & $10(28.6)$ & $2(5.7)$ & \\
\hline$>1000$ & $1(2.9)$ & $0(0)$ & \\
\hline Total & $35(100)$ & $35(100)$ & \\
\hline Mean \pm SD & $\begin{array}{l}729.31 \pm \\
172.45\end{array}$ & $\begin{array}{l}464.86 \pm \\
28\end{array}$ & $<0.001$ \\
\hline
\end{tabular}

Table 1 shows that the mean intra-operative blood loss was $729.31 \pm 172.45 \mathrm{ml}$ in group 1 and $464.86 \pm 28.00 \mathrm{ml}$ in group 2 with a $\mathrm{p}<0.001$, which is statistically highly significant. The blood loss measured in group 1 was $42.9 \%$ in range of $600-800 \mathrm{ml}$ followed by $28.6 \%$ in range of 800 $1000 \mathrm{ml}$ followed by $25.7 \%$ in range of $400-600 \mathrm{ml}$. The blood loss measured in group 2 was $54.3 \%$ in range of 200 400 followed by $28.6 \%$ in range of $400-600 \mathrm{ml}$. When the blood loss was compared among groups, $\mathrm{p}$ value between group 1 versus group 2 was found to be less than 0.001 , which is statistically highly significant.

A total of $31.4 \%$ in group 1 and $65.7 \%$ in group 2 required no intra-operative blood transfusion. On the other hand, $68.6 \%$ in group 1 and $34.3 \%$ in group 2 required blood transfusion intra-operatively with a $\mathrm{p}=0.001$. The difference observed was statistically highly significant. Mean requirement of intra-operative blood transfusion was $1.00 \pm 0.861$ units in group 1 and $0.457 \pm 0.730$ units in group 2 . When compared among groups, the difference in requirement of intra-operative blood transfusion in group 1 versus group 2 showed statistical significance with $\mathrm{p}=0.031$. A total of $54.3 \%$ women in group 1 required additional medical intervention in form of misoprostol and/or carboprost as opposed to $17.1 \%$ women in group 2 . This observation was found to be statistically highly significant with a $p<0.001 .60 \%$ women in group 1 required additional surgical intervention in form of hemostatic sutures, uterine artery ligation, balloon tamponade or combination of these. Only one patient required cesarean hysterectomy in group 1. In group 2, 17.1\% women required additional surgical intervention intraoperatively which is statistically highly significant $(p<0.05) .22 .9 \%$ women in intravenous tranexamic acid group showed nausea and vomiting post-operatively. No other side effects like thromboembolism till hospital stay or seizure episodes noted in both groups $(\mathrm{p}<0.001)$.

Table 2: Maternal complications, $(n=35)$.

\begin{tabular}{|c|c|c|c|}
\hline $\begin{array}{l}\text { Maternal } \\
\text { complications }\end{array}$ & $\begin{array}{l}\text { Group 1, } \\
\text { n }(\%)\end{array}$ & $\begin{array}{l}\text { Group 2, } \\
\text { n }(\%)\end{array}$ & $P$ value \\
\hline PPH & $26(74.3)$ & $7(20)$ & $\begin{array}{l}<0.001 \\
\mathrm{HS}\end{array}$ \\
\hline $\begin{array}{l}\text { Post-partum } \\
\text { shock }\end{array}$ & $1(2.9)$ & $0(0)$ & $\begin{array}{l}0.313 \\
\text { NS }\end{array}$ \\
\hline DIC & $0(0)$ & $0(0)$ & - \\
\hline Renal failure & $0(0)$ & $0(0)$ & - \\
\hline $\begin{array}{l}\text { Transfer to } \\
\text { ICU }\end{array}$ & $1(2.9)$ & $0(0)$ & $\begin{array}{l}0.313 \\
\mathrm{NS}\end{array}$ \\
\hline $\begin{array}{l}\text { Maternal } \\
\text { mortality }\end{array}$ & $0(0)$ & $0(0)$ & - \\
\hline
\end{tabular}

Table 2 shows most of the maternal complications were observed in group 1. In group 1, 74.3\% women developed postpartum hemorrhage (blood loss $>500 \mathrm{ml}$ ) while $20 \%$ in group 2. Only one woman in group 1 developed postpartum shock and was shifted to ICU. The $p<0.001$ in terms of postpartum hemorrhage as maternal complication which is statistically highly significant. 
Table 3: Post-operative hemoglobin level, $(\mathbf{n}=35)$.

\begin{tabular}{|c|c|c|c|}
\hline $\begin{array}{l}\text { Post-operative } \\
\text { hemoglobin } \\
\text { (g/dl) }\end{array}$ & $\begin{array}{l}\text { Group 1, } \\
\text { n }(\%)\end{array}$ & $\begin{array}{l}\text { Group 2, } \\
\text { n (\%) }\end{array}$ & $\begin{array}{l}\text { P value } \\
(95 \% \mathrm{CI})\end{array}$ \\
\hline 4.0-6.9 & $3(8.6)$ & $3(8.6)$ & \multirow{5}{*}{$\begin{array}{l}0.001 \\
{[95 \% \mathrm{CI}=-} \\
1.57 \text { to }- \\
0.05]\end{array}$} \\
\hline 7.0-8.9 & $23(65.7)$ & $9(25.7)$ & \\
\hline $9.0-10.9$ & $6(17.1)$ & $22(62.9)$ & \\
\hline$\geq 11$ & $3(8.6)$ & $1(2.9)$ & \\
\hline Total & $35(100)$ & $35(100)$ & \\
\hline Mean \pm SD & $8.04 \pm 1.34$ & $8.85 \pm 1.26$ & 0.032 \\
\hline
\end{tabular}

Table 3 illustrates mean post-operative hemoglobin was $8.04 \pm 1.34 \mathrm{~g} / \mathrm{dl}$ in group 1 and $8.85 \pm 1.26 \mathrm{~g} / \mathrm{dl}$ in group 2 . The difference in post-operative hemoglobin level was found statistically significant when compared between group 1 and group 2 with a $\mathrm{p}=0.032$. Mean change in hemoglobin concentration from pre-operative hemoglobin to post-operative hemoglobin was $1.563 \pm 0.66 \mathrm{~g} / \mathrm{dl}$ in group 1 and $0.734 \pm 0.35 \mathrm{~g} / \mathrm{dl}$ in group 2 . The difference in change in hemoglobin concentration was found statistically significant when group 1 was compared with group 2 with a $\mathrm{p}<0.001 .45 .7 \%$ women in group 1 and $11.4 \%$ in group 2 required blood transfusion postoperatively. Mean requirement of post-operative blood transfusion was $0.571 \pm 0.688$ units in group 1 and $0.20 \pm 0.575$ units in group 2. Statistically, the difference on comparing group 1 with group 2 in terms of requirement of post-operative blood transfusion was found significant with $\mathrm{p}=0.002$ respectively.

Mean birth weight was $2.28 \pm 0.53 \mathrm{~kg}$ in group 1 and $2.41 \pm 0.52 \mathrm{~kg}$ in group 2. No statistically significant difference was found ( $\mathrm{p}>0.05)$. On comparing Apgar score at 1 minute, $5.7 \%$ neonates in group 1 and $2.9 \%$ in group 2 were having score less than 7 . Similarly, $5.7 \%$ neonates in group 1 and $2.9 \%$ in group 2 were having Apgar score at 5 minute less than $7(\mathrm{p}>0.05)$. A total of $5.7 \%$ neonates in group 1 and $0 \%$ in group 2 were born with very low birth weight. On other hand, $51.4 \%$ neonates in group 1 and $45.7 \%$ in group 2 were having low birth weight. Neonates born premature were $65.7 \%$ in group 1 and $45.7 \%$ in group 2. Total $11.4 \%$ neonates were transferred to NICU in group 1 and $14.3 \%$ in group 2 . The observed difference was statistically insignificant $(\mathrm{p}>0.05)$. Most neonates were transferred to NICU due to low birth weight. Most neonates were transferred to NICU due to low birth weight i.e., $3(8.6 \%)$ in group 1 and $5(14.3 \%)$ in group 2.

Table 4: Hospital stay (days).

\begin{tabular}{|llll|}
$\begin{array}{l}\text { Hospital } \\
\text { stays (days) }\end{array}$ & $\begin{array}{l}\text { Group 1 } \\
\text { Mean } \pm\end{array}$ & $\begin{array}{l}\text { Group 2 } \\
\text { Mean } \pm\end{array}$ & $\begin{array}{l}\text { P value } \\
\text { (95\% CI) }\end{array}$ \\
\hline $\begin{array}{l}\text { Mean } \\
\text { hospital } \\
\text { stay (days) }\end{array}$ & $6.46 \pm 3.34$ & $4.31 \pm 2.53$ & $\begin{array}{l}0.011[95 \% \\
\text { CI }=0.41 \text { to } \\
3.88]\end{array}$ \\
\hline
\end{tabular}

Table 4 shows that the mean hospital stay was $6.46 \pm 3.34$ days in group 1 and $4.31 \pm 2.53$ days in group 2. The difference was found statistically significant in terms of hospital stay when group 1 was compared with group 2 with $\mathrm{p}=0.011$.

\section{DISCUSSION}

Postpartum hemorrhage is a leading cause of maternal morbidity and mortality worldwide. ${ }^{1}$ Placenta previa is one of the major causes of postpartum hemorrhage. It occurs with an incidence of $0.3-0.5 \%$ and is defined by implantation of placenta in lower uterine segment, thus partially or totally overlying the internal OS. Intraoperative management options deployed to control hemorrhage in placenta previa patients include bimanual uterine compression, implantation site compression with sutures, uterine arterial ligation, pelvic arterial embolization $^{13}$ and hysterectomy. The prevention of postpartum hemorrhage in cases of placenta previa is quite challenging. ${ }^{12,13}$

The age of the present study population ranged from 19 to 40 years with maximum number of women in the age group of 21-25 years (38.1\%). Majority of women among all groups belonged to age group of 21-30 years which could be due to the fact that it is the most reproductive age group. Mean age was $26.34 \pm 4.78$ years in group 1 and $27.31 \pm 5.62$ years in group 2. This observation was found to be statistically insignificant. Similar findings were observed in study by Shady et al where mean age was $29.5 \pm 2.42$ years in group 1 and $29.6 \pm 2.68$ years in group 2 which was statistically not significant. ${ }^{15}$ Kaur et al also concluded that maximum number of women were in age group 21-30 years. ${ }^{16}$

In the present study, most of the women in were nulliparous with no statistically significant difference ( $p>0.05$ ). Similar finding was observed by Sekiguchi et al which concluded that most women with placenta previa were nulliparous (42\%). ${ }^{17}$ Kaur et al found that more than $50 \%$ of women having placenta previa were multiparous. ${ }^{16}$

In the present study, most of the women were in body weight group more than $60 \mathrm{~kg}$. Mean body weight was $62.97 \pm 6.44 \mathrm{~kg}$ in group 1 and $63.2 \pm 6.12 \mathrm{~kg}$ in group 2 with no statistically significant difference $(p>0.05)$. Salem et al observed in their study that mean body weight was $67 \pm 5.5$ $\mathrm{kg}$ in study group versus $64 \pm 3.8 \mathrm{~kg}$ in control group with no statistically significant difference. ${ }^{18}$

In the present study, mean pre-operative systolic blood pressure was $115.49 \pm 8.7,112.74 \pm 8.79$ and $113.49 \pm 10.57$ $\mathrm{mmHg}$ in group 1 and 2 respectively, while diastolic blood pressure was $76.29 \pm 8.32$ and $75.37 \pm 8.21 \mathrm{mmHg}$ respectively. Mean pre-operative pulse rate was $94.57 \pm 8.7$ and $91.77 \pm 6.74$ per minute in group 1 and 2 respectively. The difference was statistically insignificant in terms of pre-op vitals $(\mathrm{p}=0.452$ and 0.864$)$.

The findings are in agreement to the study conducted by Salem et al were similar in study group and control 
group. ${ }^{18}$ Mean systolic blood pressure was $115 \pm 10.24$ versus $113 \pm 12.06 \mathrm{mmHg}$, diastolic blood pressure was $78.90 \pm 5.18$ versus $80.09 \pm 4.00 \mathrm{mmHg}$ and pulse rate were $85 \pm 5.7$ versus $84 \pm 4.9$ per minute in study group and control group respectively with no statistically significant difference.

In the present study, majority of the women presented with bleeding per vaginum with $91.4 \%$ in group 1 and $77.1 \%$ in group 2. Women presented with labour pains were none in group 1 and $11.4 \%$ in group $2(\mathrm{p}>0.05)$. This observation was found to be statistically insignificant. Only $6.66 \%$ women presented with labour pains as opposed to $35.8 \%$ in the study done by Sekiguchi et al in 2013. ${ }^{17}$ Lower incidence in the present study may be due to the fact that minor degree placenta previa cases delivered vaginally. No other previous study compared presenting symptoms such as bleeding per vaginum or labour pains.

Prior cesarean delivery is a risk factor for placenta previa. In present study, $22.9 \%$ women in group 1 and $20 \%$ women in group 2 had previous cesarean delivery with no statistical significance $(p>0.05)$. The incidence of prior cesarean delivery was $11.7 \%$ in the study by Sekiguchi et al, $12.05 \%$ in study by Sushma et al and $20.75 \%$ in study by Naik et al. ${ }^{17,19,20}$

In the present study, $7.6 \%$ of all women had history of previous $\mathrm{D}$ and $\mathrm{C}$ with $2.9 \%$ in group 1 and $8.6 \%$ in group 2 ( $>0.05)$. Sekiguchi et al in a study observed that previous history of $\mathrm{D}$ and $\mathrm{C}$ was found in $35.8 \%$ of women with placenta previa. ${ }^{17}$ Previous history of $\mathrm{D}$ and $\mathrm{C}$ in the present study was lesser as compared to this study which may be due to the fact that majority of women in the present study were primigravida.

In group 1, 17.1\% and in group 2, 25.7\% women presented with malpresentation. Malpresentation included breech, oblique and transverse lie. In group I1, 5.7\% women and in group 2, 2.9\% women had absent fetal heart sound on ultrasonography indicating intrauterine death of fetus at the time of presentation. This result is comparable to previous studies by Sushma et al (14.81\%), Kaur et al $(21.05 \%)$ and Naik et al $(18.87 \%) .{ }^{16,19,20}$

In the present study, most of the women who underwent cesarean delivery had type IV placenta previa i.e., $34.3 \%$ in group 1 and $48.6 \%$ in group 2 ( $p>0.05)$. The findings are comparable to the study by Kaur et al who observed $81.58 \%$ women with major degree placenta previa. ${ }^{16}$

In the present study, mean pre-operative hemoglobin level was $9.57 \pm 1.54 \mathrm{~g} / \mathrm{dl}$ in group 1 and $9.59 \pm 1.35 \mathrm{~g} / \mathrm{dl}$ in group 2 ( $>>0.05)$. In study by Yehia et al found that pre-operative hemoglobin level was $11.8 \pm 1.5 \mathrm{~g} / \mathrm{dl}$ in study group and $11.9 \pm 1.2 \mathrm{~g} / \mathrm{dl}$ in control group with no statistical significance $\left((\mathrm{p}>0.05) .{ }^{21}\right.$ Shady et al pre-operative hemoglobin level was $9.89 \pm 0.66$ and $9.89 \pm 0.67 \mathrm{~g} / \mathrm{dl}$ in group 1 and 2 respectively $(\mathrm{p}>0.05) .{ }^{15}$
In the present study, the mean pre-operative INR was $1 \pm 0.12$ in group 1 and $0.99 \pm 0.14$ in group $2(p>0.05)$. The mean pre-operative platelet count was $2.07 \pm 0.71$ and $2.01 \pm 0.39$ and $1.97 \pm 0.42$ lac in group 1 and 2 . These observations were statistically insignificant $(\mathrm{p}>0.05)$.

In present study, 5.8\% women in group 1 and $8.6 \%$ in group required pre-operative blood transfusion in the form of packed cell. Mean requirement of pre-operative blood transfusion was $0.086 \pm 0.368$ units in group 1 and $0.143 \pm 0.486$ units in group $2(\mathrm{p}>0.05)$.

Prematurity is a consistent finding in babies of women with placenta previa. In the present study, $60 \%$ women underwent preterm cesarean delivery i.e., before 37 weeks of gestation. Mean gestational age at delivery was $35.77 \pm 2.66$ weeks in group 1 and $36.69 \pm 2.35$ weeks in group 2 with no statistical significance ( $p>0.05)$. Similarly, Shady et al observed that the mean gestational age was $36.38 \pm 0.87$ weeks in group 1 and $36.45 \pm 0.90$ weeks in group 2 with no statistical significance $(\mathrm{p}>0.05) .{ }^{15}$

In the present study, mean blood loss was $729.31 \pm 172.45$ $\mathrm{ml}$ in group 1 and $464.86 \pm 28.00 \mathrm{ml}$ in group 2 with a $\mathrm{p}<0.001$ which was statistically highly significant. Similar results were depicted from study by Shady et $\mathrm{al}^{15}$ in which mean intraoperative blood loss was $918 \mathrm{ml}$ in group 1 and $532 \mathrm{ml}$ in group 2. Present study is comparable to other study by Shahid et al which concluded that intravenous tranexamic acid significantly reduced the quantity of blood loss from placental delivery to the end of cesarean section which was $356.44 \pm 148.20 \mathrm{ml}$ in tranexamic acid group versus $710.22 \pm 216.72 \mathrm{ml}$ in placebo group $(\mathrm{p}<0.001) .{ }^{22}$

In the present study, $68.6 \%$ women in group 1 and $34.3 \%$ in group 2 required blood transfusion intra-operatively. This difference was found statistically significant in both cases when group 1 was compared to group 2 with a $\mathrm{p}=0.001$. Mean requirement of intra-operative blood transfusion was $1.00 \pm 0.861$ units in group 1 and $0.457 \pm 0.730$ units in group 2 . Present study shows that the use of tranexamic acid in cesarean section reduces the need of intra-operative blood transfusion. Reducing intraoperative blood loss would lower the risks and cost associated with blood transfusion. Our findings are in agreement with that of study by Shahid et al. ${ }^{22} \mathrm{He}$ observed that $33 \%$ women required blood transfusion in placebo group as compared to intravenous tranexamic acid group in which only $8 \%$ of women required the blood transfusion.

Present study is comparable to the study conducted by Sujata et al in which $83 \%$ women in control group and $23 \%$ women in intravenous tranexamic acid group needed additional uterotonics intra-operatively $(\mathrm{p}<0.001)$. This study concluded that intravenous tranexamic acid administered at least 10 minutes before skin incision, significantly reduced the requirement for additional uterotonic drugs. ${ }^{23}$ 
The present study showed that $60 \%$ women in group 1 required additional intra-operative surgical intervention in form of hemostatic sutures, uterine artery ligation, balloon tamponade or combination of these. In group 2, $17.1 \%$ women required additional surgical interventions $(\mathrm{p}=0.001)$. Our findings are comparable to that of previous study by Shady et al in which $52.5 \%$ women in control group required additional intra-operative surgical interventions in form of uterine artery ligation and internal iliac artery ligation while $17.5 \%$ required surgical intervention in intravenous group $(\mathrm{p}=0.001){ }^{7,9}$

Tranexamic acid administered intravenously caused nausea and vomiting in $22.9 \%$ women $(\mathrm{p}<0.001)$. Our results are in accordance with study done by Shady et al which concluded that the incidence of nausea and vomiting was higher in intravenous tranexamic acid group $(22.5 \%) .{ }^{15} \mathrm{Xu}$ et al in a study found that incidence of sideeffects like nausea, vomiting and dizziness was higher in intravenous tranexamic acid group compared to control group with $\mathrm{p}<0.01 .{ }^{24}$

In the present study, most of the maternal complications were observed in group 1. Incidence of postpartum hemorrhage was $74.3 \%$ in group 1 and $20 \%$ in group 2 with a $\mathrm{p}<0.001$. Only one patient was transferred to ICU post-operatively in group1 because of post-partum shock. Patient stayed in ICU for five days and was discharged on post-operative day 10 . There was no maternal mortality in the present study. These findings are similar to study done by Salem et al in which incidence of postpartum hemorrhage was $59.3 \%$ in control group versus $24.9 \%$ in intravenous tranexamic acid group $(\mathrm{p}<0.001){ }^{18}$

Mean post-operative hemoglobin was $8.04 \pm 1.34 \mathrm{~g} / \mathrm{dl}$ in group 1 and $8.85 \pm 1.26 \mathrm{~g} / \mathrm{dl}$ in group $2(\mathrm{p}<0.05)$ which is statistically significant. In the study by Shady et al mean post-operative hemoglobin was $8.63 \pm 0.96 \mathrm{~g} / \mathrm{dl}$ and $9.04 \pm 1.01 \mathrm{~g} / \mathrm{dl}$ in group 1 and 2 respectively with no statistical significance $(\mathrm{p}>0.05){ }^{15}$

Mean decline in hemoglobin concentration was $1.563 \pm 0.66 \mathrm{~g} / \mathrm{dl}$ in group 1 and $0.734 \pm 0.35 \mathrm{~g} / \mathrm{dl}$ in group 2 with $\mathrm{p}<0.001$. Similar to the present study, Roy et al had comparable results in which decline in hemoglobin concentration was $0.26 \pm 0.22 \mathrm{~g} / \mathrm{dl}$ in tranexamic acid group and $0.99 \pm 0.48$ in control group. ${ }^{25}$ This study observed that the use of tranexamic acid in cesarean section led to less decline in hemoglobin concentration post-operatively $(\mathrm{p}<0.001)$.

It was observed in the present study that $45.7 \%$ women in group 1 and $11.4 \%$ women in group 2 required blood transfusion post operatively ( $\mathrm{p}<0.001)$. Mean requirement of post-operative blood transfusion was $0.571 \pm 0.688$ units in group 1 and $0.20 \pm 0.575$ units in group 2. Hence use of tranexamic acid intravenously significantly reduced the need for post-operative blood transfusion. This is because of the fact that tranexamic acid reduced perioperative blood loss and incidence of postpartum hemorrhage.
Prematurity is a consistent finding in neonates born to women with placenta previa. In the present study, $57.1 \%$ neonates in group 1 and $45.7 \%$ in group 2 were having low birth weight. Mean birth weight was $2.28 \pm 0.53 \mathrm{~kg}$ in group 1 and $2.41 \pm 0.52 \mathrm{~kg}$ in group $2(\mathrm{p}>0.05)$.

The safety of giving tranexamic acid intravenously while the fetus was still in utero was a key concern. As a consequence, the neonatal outcome was meticulously evaluated by a neonatologist. In the present study, Apgar score of less than 7 at 1-minute and 5-minute was observed in $5.7 \%$ neonates in group 1 and $2.9 \%$ neonates in group 2 ( $p>0.05$ ). Similarly, study conducted by Roy et al found that the mean Apgar score at 1-minute and 5-minute were $7.06 \pm 1.25$ and $8.66 \pm 1.00$ in the study group and $7.18 \pm 1.35$ and $8.64 \pm 0.98$ in the control group respectively $(\mathrm{p}>0.05) .{ }^{25}$

In the present study, $11.4 \%$ neonates in group 1 and $14.3 \%$ neonates in group 2 were transferred to NICU ( $>>0.05)$. Mean hospital stay in the present study was $6.46 \pm 3.34$ days in group 1 and $4.31 \pm 2.53$ days in group $2(\mathrm{p}<0.001)$.

\section{CONCLUSION}

In the present study, it was observed that tranexamic acid significantly reduced intra-operative blood loss. It also reduced the incidence of postpartum hemorrhage, need of additional uterotonics, need for intra-operative surgical interventions, intra-and post-operative blood transfusion and led to less decline in hemoglobin concentration postoperatively. Tranexamic acid had no effect on Apgar score, perinatal outcome, NICU transfer, low birth weight or respiratory distress syndrome.

\section{Funding: No funding sources}

Conflict of interest: None declared

Ethical approval: The study was approved by the Institutional Ethics Committee

\section{REFERENCES}

1. Prata N, Gerdts C. Measurement of postpartum blood loss. BMJ. 2010;340:c555.

2. Abou Zahr C. Global burden of maternal death and disability. Br Med Bull. 2003;67:1.

3. Kambo I, Bedi N, Dhillon BS, Saxena NC. A critical appraisal of cesarean section rates at teaching hospitals in India. Int J Gynecol Obstet. 2002;79:1518.

4. Magann EF, Evans S, Hutchinson M, Collins R, Lanneau G, Morrison JC. Postpartum hemorrhage after cesarean delivery: an analysis of risk factors. South Med J. 2005;98:681-6.

5. Kramer MS, Berg C, Abenhaim H, Dahhou M, Rouleau J, Mehrabadi A et al. Incidence, risk factors, and temporal trends in severe postpartum hemorrhage. Am J Obstet Gynecol. 2013;209:449-e1.

6. Bateman BT, Berman MF, Riley LE, Leffert LR. The epidemiology of postpartum hemorrhage in a large, 
nationwide sample of deliveries. Anesth Analg. 2010;110:1368-73.

7. Oppenheimer L. Society of obstetricians and Gynecologists of Canada. Diagnosis and management of placenta previa. J Obstet Gynecol Can. 2007;29:261-73.

8. Reddy UM, Abuhamad AZ, Levine D, Saade GR. Executive summary of a joint Eunice Kennedy Shriver National Institute of Child Health and Human Development, Society for Maternal-Fetal Medicine, American Institute of Ultrasound in Medicine, American College of Obstetricians and Gynecologists, American College of Radiology, Society for Pediatric Radiology, and Society of Radiologists in Ultrasound fetal imaging workshop. Obstet Gynecol. 2014;123:1070-82.

9. Al-Harbi NA, Al-Abra ES, Alabbad NS. Uterovaginal packing. Saudi Med J. 2009;30:243-6.

10. Frenzel D, Condous GS, Papageorghiou AT, McWhinney NA. The use of the 'tamponade test to stop massive obstetric haemorrhage in placenta accreta. BJOG: Int J Obstet Gynecol. 2005;112:6767.

11. B-Lynch C, Coker A, Lawal AH, Abu J, Cowen MJ. The B-Lynch surgical technique for the control of massive postpartum haemorrhage: an alternative to hysterectomy? Five cases reported. BJOG: Int J Obstet Gynecol. 1997;104:372-5.

12. Tjalma WA, Jacquemyn Y. Compression sutures instead of emergency peripartum hysterectomy. Eur J Obstet Gynecol Reprod Biol. 2005;118:258.

13. Clark SL, Phelan JP, Yeh SY, Bruce SR, Paul RH. Hypogastric artery ligation for obstetric hemorrhage. Obstet Gynecol. 1985;66:353-6.

14. WOMAN Trial Collaborators. Effect of early tranexamic acid administration on mortality, hysterectomy, and other morbidities in women with post-partum haemorrhage (WOMAN): an international, randomized, double-blind, placebocontrolled trial. Lancet. 2017;389:2105.

15. Shady NW, Sallam HF. Adjunctive IV tranexamic acid versus topical tranexamic acid application of the placental bed for prevention of postpartum hemorrhage in women with placenta previa: a randomized controlled trial. Int J Reprod Contracept Obstet Gynecol. 2017;6:5205-12.

16. Kaur K, Garg R, Kaur A, Jindal R. Feto-maternal outcome in placenta previa with unscarred uterus (one-year prospective study). Parity. 2018;36:2-62.

17. Sekiguchi A, Nakai A, Kawabata I, Hayashi M, Takeshita T. Type and location of placenta previa affect preterm delivery risk related to antepartum hemorrhage. Int J Med Sci. 2013;10:1683.

18. Salem MN, Mohamed MA, Salem AH, Abbas A. Tranexamic acid as prophylactic therapy for intra- and post-partum hemorrhage: randomized controlled trial. J Adv Med Med Res. 2016;17:1-7.

19. Lama S, Ranjit S. Study on maternal and immediate fetal outcome of placenta previa. Nepal J Obstet Gynecol. 2016;11:24-7.

20. Naik VR, Cardoso PM. A study of proportion, maternal and fetal outcomes in cases of placenta previa. IOSR-JDMS. 2018;17:1-5.

21. Yehia AH, Koleib MH, Abdelazim IA, Atik A. Tranexamic acid reduces blood loss during and after cesarean section: a double blinded, randomized, controlled trial. Asian Pac J Reprod. 2014;3:53-6.

22. Shahid A, Khan A. Tranexamic acid in decreasing blood loss during and after caesarean section. J Coll Physicians Surg Pak. 2013;23:459-62.

23. Sujata N, Tobin R, Kaur R, Aneja A, Khanna M, Hanjoora VM. Randomized controlled trial of tranexamic acid among parturients at increased risk for postpartum hemorrhage undergoing cesarean delivery. Int J Gynecol Obstet. 2016;133:312-5.

24. $\mathrm{Xu} \mathrm{J}$, Gao W, Ju Y. Tranexamic acid for the prevention of postpartum hemorrhage after cesarean section: a double-blind randomization trial. Arch Gynecol Obstet. 2013;287:463-8.

25. Roy I, Chakraborty S, Mukhopadhya S. Role of intravenous tranexamic acid on cesarean blood loss: a prospective randomized study. Trop J Obstet Gynecol. 2018;35:49-53.

Cite this article as Rathore M, Gupta A, Kumari N. Efficacy of prophylactic tranexamic acid administration in prevention of postpartum hemorrhage in placenta previa cesarean section: an interventional study. Int J Reprod Contracept Obstet Gynecol 2022;11:153-9. 